\title{
Responses to the Holocaust in Modern Irish Poetry
}

\author{
Benjamin Keatinge \\ South East European University, Macedonia
}

Copyright (c) 2011 by Benjamin Keatinge. This text may be archived and redistributed both in electronic form and in hard copy, provided that the author and journal are properly cited and no fee is charged for access.

\begin{abstract}
This essay examines twentieth and twenty-first century responses by Irish poets to the Holocaust. It argues that, despite the illiberal tendencies of the Irish state towards Jewish immigration during and after the 1939-1945 war, recent commemorative activities in Ireland have included the Holocaust and are part of a wider commemorative 'opening up' in Ireland towards twentieth-century historical events. Important contemporary Irish poets have written Holocaust poems of notable merit including: Seamus Heaney, Harry Clifton, Derek Mahon, Pearse Hutchinson, Paul Durcan, Paul Muldoon, Thomas Kinsella and Tom Paulin, all of whom are discussed here. These poets are noted as second-generation Holocaust poets, more at home in the lyric form and less troubled by communicative dilemmas than their precursors such as Paul Celan and Samuel Beckett whose resemblance is briefly discussed. The essay concludes by arguing that Giorgio Agamben's arguments about testimony after Auschwitz are strikingly pertinent to some of the poems under discussion. It also suggests that the historical essays of Hubert Butler may have acted as an unseen influence on some of these writers.
\end{abstract}

Key Words. Holocaust, Ireland, poetry, commemoration, memory, testimony, history, language.

Resumen. El ensayo examina la respuesta de los poetas irlandeses del siglo XX y XXI al Holocausto. Sostiene que a pesar de las actitudes intolerantes del estado irlandés hacia la inmigración judía durante y después de la guerra de 1939-1945, actos conmemorativos recientes han incluido el Holocausto y forman parte de una más amplia apertura de Irlanda en relación a la conmemoración de acontecimientos históricos del siglo XX. Reconocidos poetas irlandeses contemporáneos han escrito poemas de notable mérito sobre el Holocausto, incluyendo a Seamus Heaney, Harry Clifton, Derek Mahon, Pearse Hutchinson, Paul Durcan, Paul Muldoon, Thomas Kinsella y Tom Paulin, todos los cuales serán objeto de nuestra atención. Se trata de poetas del Holocausto de segunda generación, más familiarizados con la forma lírica y menos preocupados por dilemas comunicativos que precursores tales como Paul Celan y Samuel Beckett, cuya semblanza se esbozará brevemente. El ensayo concluye apuntando que las ideas de Giorgio Agamben en torno al testimonio después de Auschwitz son sorprendentemente pertinentes en algunos de los poemas analizados. También se sugiere que los ensayos históricos de Hubert Butler pueden haber ejercido una influencia velada en alguno de estos escritores.

Palabras clave. Holocausto, Irlanda, poesía, conmemoración, memoria, testimonio, historia, lengua.

Any consideration of the response by twentieth and twenty-first century Irish poets to the Holocaust must first consider the historical context of Ireland's small Jewish community and the record of pre-war and wartime immigration into Ireland by refugees from mainland Europe. Available census statistics show that from 1861 onwards there was a

ISSN 1699-311X 
small but significant Jewish community in Ireland, mainly based in Dublin but also in cities such as Cork and Limerick. The 1901 census, taken three years before the 1904 setting of James Joyce's Ulysses (1922) suggests that there were just over 3,000 Jews living in Ireland out of a total population of roughly 3,200,000. By 1946, this number had risen only to 5,381 professing Jews on the island of Ireland. These statistics tell their own story of Ireland's pre-war and wartime inaction in the face of mass expulsions from central and eastern Europe. Even during the years of the Holocaust, 1942-45, Irish policy was parsimonious, at best, and according to Dermot Keogh's authoritative study Jews in TwentiethCentury Ireland (1998), the number admitted during the Second World War "may have been as few as sixty" (Keogh 1998: 192).

These figures should be set against some mitigating factors. Eamon de Valera as Ireland's wartime Taoiseach was broadly philo-Semitic and indeed a personal friend of independent Ireland's first chief rabbi Dr Isaac Herzog. Keogh's history shows that as the refugee crisis worsened after Kristallnacht (November 1938), de Valera did sometimes intervene in the decision making powers of the monolithic Department of Justice whose attitude can best be summarised by Minister Patrick Ruttledge's sentiments, in a letter to Ireland's (then) only Jewish politician in Dáil Éireann, Robert Briscoe in April 1938:

In general, I think that the Jewish community in this country should not be increased by way of immigration, except in cases where the immigrant is a definite acquisition to the State. So long as we have ... the problem of unemployment, I feel that it is wrong to admit aliens about whom we cannot be certain that they will not compete with our own citizens in the labour market (cited in Keogh 1998: 125).

While Ireland remained very much a closed society before and during 'The Emergency', Keogh's study shows that the Jewish community which did exist were almost entirely spared the anti-Semitic excesses of mainland Europe. In this sense, Ireland was a safe haven, albeit one which most immigrants could not reach. The only major anti-Semitic disturbance in twentieth-century Ireland took place in Limerick in January 1904 (the socalled 'Limerick pogrom'), but Keogh shows that this amounted more to a boycott than a fully-fledged pogrom and the authorities were largely successful in minimising violence and restoring order and normality. Keogh's study suggests that the conservative and homogeneic tendencies of the new State coexisted with reasonably tolerant attitudes amongst the general populace. This notwithstanding, Keogh's study also confirms that Ireland's retrenchment and isolation during the 1930s and 1940s militated against any genuinely enlightened refugee policy and the Ireland which the Jewish community lived in was, if anything, less open-minded than Leopold Bloom's Dublin of 1904. Joyce's celebrated philo-Semitism, vividly played out in Stephen's encounter with Mr Deasy and Bloom's encounter with the Citizen in Ulysses, serves to underline the tensions between both imperial (pro-British) and ultra-nationalist prejudice, on the one hand, and the condition of the 'alien' in Irish society, on the other, without, however, exaggerating the ideological capacity of such extremes to do the same violence to the resident 'other' as was witnessed in wartime Europe. ${ }^{1}$ Ireland shares with other west European countries, the implicit violence of inaction and inertia during the 1930s and 1940s, sins of omission rather than actual persecution of Jewish or other immigrant communities.

As Joyce's novel makes clear, history is never far from present-day politics. The imperialistic $\mathrm{Mr}$ Deasy regards the British Empire as God's kingdom on earth whereas the Citizen is the archetypal xenophobic Irish nationalist who despises foreigners, especially the English. These polarised attitudes from which Stephen and Bloom try to escape - the nets of history - are reflected also in contemporary reactions to 'The Emergency'. On the nationalist side there were many Nazi sympathisers while the more Anglo-Irish sections of Irish society sided with Britain and the Allies and many joined the British ranks to fight against Hitler. Meanwhile, de Valera's government attempted to steer a middle course while tacitly assisting the Allied cause.

1. For general consideration of Irish refugee policy with a cultural emphasis and coverage of Jewish issues, see: Bryan Fanning, Racism and Social Change in the Republic of Ireland (Manchester: Manchester University Press, 2002) and John Brannigan, Race in Modern Irish Literature and Culture (Edinburgh: Edinburgh University Press, 2009). 
What we might call Ireland's 'museum of history' was and remains an arena where partisan sympathies adapt history for presentday purposes; this is, one might suggest, an almost universal phenomenon. However, the recent past (say, 1985 onwards) suggests that a less biased, more 'objective' treatment of history has influenced the Irish polity ${ }^{2}$ and this is directly connected with the way in which Irish society has remembered a range of historical events including: the 1916 Rising, the First World War, the War of Independence, the Civil War, the Second World War and Holocaust. In 1968 (the year before the Northern Irish troubles began), the poet Richard Murphy published his long historical poem The Battle of Aughrim which starts with the question:

Who owns the land where musket-balls are buried In blackthorn roots on the esker, the drained bogs Where sheep browse, and credal war miscarried? (Murphy 2000: 61)

By choosing a fateful military encounter of 1691 between Irish Catholic Jacobite forces and forces loyal to King William of Orange on a battlefield near modern-day Ballinasloe, Co. Galway, Murphy gives us a panoramic view of Irish history arranged according to chronology: 'Now' (section 1), 'Before' (section 2), 'During' (section 3) and 'After' (section 4). His short poem 'History' from the first section confirms that: "The past is happening today" (Murphy 2000: 67) and as Murphy resurrects this distant battle, he is also able to survey the current (1966) Irish political establishment gathered at Glasnevin cemetery for the reinterment of Roger Casement's remains:

2. In his book The Irish Story, historian R.F. Foster comments: “ ... from the 1960s, the questioning of accepted versions of Irish history began to take firmer and firmer hold, and to advance from academic orthodoxy into public debate. Irish historians, working in many areas, tried to break up the seamless construction of narrative incident which was presented as the story of Ireland, and to analyse the moment, rather than simply follow the flow.” (Foster 2001: 2). R.F. Foster's earlier study Modern Ireland 1600-1972 (London: Penguin, 1989) can be taken as a high-water mark of Irish historical revisionism which put into question many received opinions about 'the Irish story’.
On the small screen I watch the packed cortège Pace from High Mass. Rebels in silk hats now Exploit the grave with an old comrades speech: White hair tossed, a black cape flecked with snow.

(Murphy 2000: 64)

The fading revolutionaries are a mirror of a de-energised Ireland still trying to reinvigorate itself fifty years after the Easter Rising.

By contrast, more recent commemorative events have had far greater political vigour. In November 1998, seven months after the Good Friday agreement was signed, the Island of Ireland Peace Park was opened at Messines, near Ypres, Belgium with the intention of commemorating the 40,000 or so Irish soldiers, from both the North and the South, killed during the First World War. An earlier initiative had seen the Irish National War Memorial Gardens at Islandbridge, Dublin renovated and reopened in September 1988 prior to a major public commemoration in July 2006 on the ninetieth anniversary of the Battle of the Somme. Superficially, these commemorative events would seem to be in line with French historian Pierre Nora's distinction between lieu de mémoire and actual living memory, the implication being that as living memory fades, formal commemoration based around lieu de mémoire becomes more conspicuous. However, in the case of the First World War in Ireland, these commemorations actually reflect a huge upsurge in public interest and debate on Ireland's role in the Great War including the testimony of those few veterans who remained. A too rigid distinction between what Nora calls the "sites of memory" and "real environments of memory" would therefore seem inappropriate in this case (Nora 1989: 7). Equally, the commemoration of the Holocaust (including the testimony of Holocaust survivors living in Ireland) has gained impetus in Ireland with the inauguration in 2003 of an Irish event for Holocaust Memorial Day (held each year around the anniversary of the liberation of Auschwitz, 27 January 1945). This stands alongside the important educational work performed by the Irish Holocaust Educational Trust set up in 2004 in the wake of the Stockholm International Forum on the Holocaust (January 2000) in which Ireland was one of 44 countries who participated and signed a joint Declaration condemning Nazi atrocities and reaffirming human rights. 
Equally significant was the earlier opening on 20 June 1985 of the Irish Jewish Museum in Walworth Road, Portobello, Dublin in the neighbourhood where many Irish Jews resided in the first-half of the twentieth century, known locally as 'Little Jerusalem'.

We see clearly that commemorative practices have greatly amplified and diversified in Irish society since Richard Murphy wrote the Battle of Aughrim. Rather than attribute this to some misalignment of history and memory (as Nora might contend), I would suggest that it is attributable to a wider 'opening up' of Irish society as it gradually discards its earlier insular and introverted political stance. This gradual evolution, from Ireland's involvement in the UN under de Valera, to the liberalisation of trade under Seán Lemass, to accession to the EU in 1973 and the election of Mary Robinson as President in 1990 has been reflected in the realms of historiography and memorial culture. If, for many years, the practice of memory was, as R.F. Foster suggests, "recognised by the widespread practice of its obverse: therapeutic voluntary amnesia” (Foster 2001: 58), then more recent decades have seen a healthy outgrowth of voluntary memory and commemoration. In this essay, I will contend that in some respects, the course of twentiethcentury Irish poetry also reflects this 'opening up' to a more international perspective so that at least some of the more national and nationalist preoccupations have been overtaken by a far more global point of view. In an age of travel and communications, we might say that this is no surprise; but given the intensely local nature of much Irish poetry (Kavanagh's parochialism, Heaney’s Mossbawm, Murphy's Connemara locales), this has involved a certain transformative aesthetic. I will also contend that the evolution of poetry about the Holocaust written by Irish poets reflects this new-found internationalism.

In a recent, and widely-read Holocaust novel - The Reader by Bernhard Schlink - the narrator, Michael Berg, reminds us of the extent to which the Holocaust has entered the general imagination in a way which those born immediately after the war might not have foreseen. In Schlink's novel, the narrator becomes a kind of secondary victim due to his adolescent relationship with a former SS guard called Hanna Schmitz leading him to reflect on the effects of the Holocaust on those who came after:

When I think today about those years, I realize how little direct observation there actually was, how few photographs that made life and murder in the camps real. We knew the gate of Auschwitz with its inscription, the stacked wooden bunks, the piles of hair and glasses and suitcases; we knew the building that formed the entrance to Birkenau with the tower, the two wings, and the entrance for the trains; and from Bergen-Belsen the mountains of corpses found and photographed by the Allies at the liberation. We were familiar with some of the testimony of prisoners, but many of them were published soon after the war and not reissued until the 1980 s, and in the intervening years they were out of print. Today there are so many books and films that the world of the camps is part of our collective imagination and completes our ordinary everyday one (Schlink 2007: 146-147).

Schlink's narrator is surely correct to point to the 'everydayness' of the Holocaust. But the postwar environment was less conducive to such recollection. Historians have attributed this type of "voluntary amnesia" to a variety of causes: the need for victims to move on from the trauma of war and establish new lives; the need for governments to reconstruct ruined economies; and, not least, the beginnings of the Cold War in the late 1940s which meant that, in Germany and Austria, some former Nazis were rehabilitated with unseemly swiftness. With the Soviet occupation of eastern Europe, a ruined Germany and Austria had to be economically and militarily secure for the west while in the east, the Soviets were more concerned with establishing communist hegemony than with pursuing war criminals. It is the distance of the Holocaust from us which has enabled it to become 'everyday'; as a recent memory it was simply insupportable both on the individual and national level as well as being inexpedient politically. I would suggest that Irish poets have the advantage of distance shared by postwar generations with no direct contact with the deathcamps and that the 'everydayness' of the Holocaust legitimates writing from any informed quarter (it was, after all, the Australian novelist Thomas Keneally who wrote the most famous work of Holocaust literature, Schindler's Ark, later filmed by Steven Spielberg as the award winning movie, Schindler's List). Equally, Ireland's "therapeutic voluntary amnesia" about certain aspects of its own past, not least the participation of southern Irishmen in the First 
Word War, is interestingly reflected in European reactions to the Holocaust immediately after the war.

Critics of Holocaust literature often draw a sharp distinction between primary witnesses, such as Paul Celan and Primo Levi, who were themselves victims of Nazi policies and secondary witnesses, those writers who come after the atrocity and rely on the first-hand reports of others. It has been suggested that the poetic testimonies of first-generation Holocaust poets (Paul Celan, Nelly Sachs, Tadeusz Borowski to name three) are deeply imbued with lyric uncertainty as if language itself is implicated in the catastrophe. As critic Susan Gubar explains:

... if language was therefore itself an instrument and casualty of the disaster, then literary artists confronted a confounding perplexity about their own medium, as Adorno knew they would. The enormity of the event, coupled with this suspicion about political or aesthetic productions, often propelled poets in two diametrically opposed directions: on the one hand, towards ellipses, fragmentation, in short poems that exhibit their inadequacy by shutting down with a sort of premature closure; on the other, toward verbosity in long poems that register futility by reiterating an exhausted failure to achieve closure. (Gubar 2004: 443)

The linguistic dilemmas of Celan and Sachs have not troubled to the same extent the surprisingly large number of Irish poets who have written about the Holocaust - including: Seamus Heaney, Paul Durcan, Pearse Hutchinson, Micheal Longley, Micheal O’Siadhail, Harry Clifton, Derek Mahon and Tom Paulin - who remain rooted in a mainly lyric tradition. However, the important exception here is one of Ireland's most renowned writers, Samuel Beckett.

As is well-known, Beckett was deeply involved in the struggle against Nazism choosing to join the Resistance in Paris in 1940 and then fleeing into Vichy France after his resistance cell was betrayed and spending the rest of the war in hiding in Roussillon in the Vaucluse where he worked on his last English novel Watt (published in 1953) before turning to French in the famous postwar 'siege in the room' when he wrote the Trilogy: Molloy, Malone Dies, The Unnamable as well as En attendant Godot (first performed in 1953). Beckett's doubts about the referentiality of language and the powers of words to communicate or convey meaning are famously present in all of these works. Even though Beckett never met Celan, there is a powerful sense that both these writers understood the implications of the Holocaust for language and for the terms in which art and poetry should be thought of in the future. On one occasion (March 1970) Celan almost met Beckett in Paris and is reported to have said: "that's probably the only man here I could have had an understanding with" (Nixon 2007: 155).

There is a growing critical literature on Beckett and the Holocaust / Second World $\mathrm{War}^{3}$, but I wish to confine my remarks to Beckett's involvement from August 1945 to January 1946 with the Irish Red Cross Hospital, Saint-Lô, Normandy. The town of Saint-Lô had been bombed out of existence during the D-Day landings in June-July 1944 thereby earning it the title 'The Capital of Ruins'. This was the title Beckett chose for a short prose talk he was scheduled to deliver on RTE radio (the Irish national broadcaster). In the event, Beckett did not deliver the talk, but this enigmatic piece of writing has since become part of his oeuvre and was published in Beckett's The Complete Short Prose 19291989 (1995). Beckett describes the makeshift buildings of the Irish Hospital in terms of their fitness for purpose and functionality:

The buildings consist of some prefabricated wooden huts. They are superior, generally speaking, to those so scantily available for the wealthier, the better-connected, the astuter or the more flagrantly deserving of the bombedout. Their finish, as well without as within, is the best that their priority can command. They are lined with glass-wool and panelled in isorel,

3. See, for example, Jackie Blackman, 'Beckett Judaizing Beckett: "a Jew from Greenland" in Paris' in Samuel Beckett Today/Aujourd'hui 18 (2007), pp.325-340; James McNaughton, 'Beckett, German Fascism and History: The Futility of Protest in Samuel Beckett Today/Aujourd'hui 15 (2005), pp.101-116; Jackie Blackman, 'Beckett's Theatre "After Auscwitz", in Samuel Beckett: History, Memory, Archive, ed. Seán Kennedy and Katerine Weiss (New York: Palgrave Macmillan, 2009), pp.71-87. James Knowlson's authoritative biography Damned to Fame: The Life of Samuel Beckett (London: Bloomsbury 1996) gives the most complete account to date of Beckett's war years. 
a strange substance of which there are only very limited supplies available. There is real glass in the windows. (Beckett 1995: 275)

Beckett goes on to consider more widely the humanitarian implications of the Irish Hospital and to draw some ethical and philosophical conclusions therefrom. For Beckett, Saint-Lô represents "a time-honoured conception of humanity in ruins” (Beckett 1995: 278). The slow process of reconstruction and the provisionality of the buildings are emblematic of both the timelessness of suffering and its temporality and specificity, an idea which lies behind Beckett's short poem 'Saint-Lô' (1946):

\begin{abstract}
Vire will wind in other shadows unborn through the bright ways tremble and the old mind ghost-forsaken

sink into its havoc (Beckett 1986: 32).
\end{abstract}

Saint-Lô and the Second World War generally acted as an objective correlative for Beckett confirming his own pessimism. The suffering of war is keenly felt and the Holocaust is, arguably, a present absence here (as perhaps in other Beckett works) informing the timbre of the poem without specific allusiveness. Beckett's short elliptic poems, including the later Mirlitonnades (1979), seem to be part of the inner landscape of suffering (in this they resemble many of Celan's poems), but the outer landscape of suffering is implied also. When Beckett states in 'The Capital of Ruins' that " 'Provisional' is not the term it was, in this universe become provisional" (Beckett 1995: 278) he is referring to a paradoxical situation where, in war-torn Europe full of stateless refugees, a provisional home is as good as any other, indeed is the new normality in the extreme conditions of 194546. This is also a new (but also old) way of conceiving humanity: destitute, homeless, in ruins which we would later equate with the adjective 'Beckettian'.

It is significant therefore that the Irish Hospital at Saint-Lô was a temporary structure built to provide immediate relief but not as a permanent building. In this it goes against all the principles of museums and monuments which are built with precisely the opposite intention. And there is surely a political statement being made here which reacts against the grotesqueries of Hitler's one thousand year Reich towards a more provisional sense of contemporary history and architecture. It is largely a point about power and the abuse of power. Permanent monuments imply lasting edifices and traditions which are generally conservative and sometimes Fascist. Temporary structures belong to the powerless, the disenfranchised who in 1945 constituted a displaced majority in Europe.

This is the very point taken up by poet Tom Paulin in his poetry on the Second World War. His long poem 'The Caravans on Lüneberg Heath' (from Fivemiletown, 1987) concerns precisely a temporary structure referring (in part) to the mobile Head Quarters of Field Marshal Bernard Montgomery who accepted the surrender of German forces on Lüneberg Heath on 4 May 1945. This poem and a second poem 'Schwarzwald oder Bauhaus' (from The Invasion Handbook, 2002) dramatise an argument about the comparative value of a rooted, stable social order versus the potential benefits of a mobile 'deterritorialised' social order. Paulin refers to German philosopher Martin Heidegger, whose views on 'rootedness' were outspoken and are dramatised by Paulin as pro-Nazi and conservative:

\section{the inner relationship of my own work to the Black Forest and its people comes from a centurieslong and irreplaceable rootedness in the Alemannian Swabian soil} (Paulin 2002: 88)

If Heidegger was "without conscience" (Paulin 1993: 107) in his notorious collusion with the Nazis, his complicity is part of a philosophy which seeks to evade core aspects of modernity - social mobility, communications, technology, 'provisionality' which Nazism, as a mobile political force, both embraced and, in other ways, resisted. The paradoxical modernity and primitive aspects of Nazism, and its co-option of modern technology for murderous purposes, would have been evident to Heidegger even from the distance of his Black Forest retreat. In terms of memory, Heidegger sides with the indigenous and traditional values of Nora's "real environments of memory" presumably found amongst the Black Forest peasantry whom he praises. Paulin deliberately counters this, in 'Schwarzwald oder Bauhaus', by contrasting Heidegger's rootedness with Le Corbusier's modernist and functional architecture in his "residence machine” (Paulin 2002: 91) method 
of urban design which, in the words of Paulin's poem, consists of:

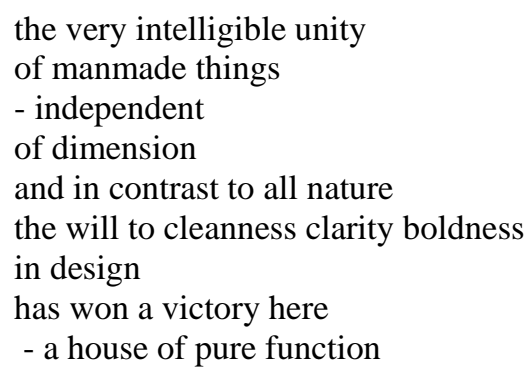

Thus, Beckett's hospital huts, the mobile caravans on Lüneberg heath used by the Allies and Le Corbusier's dynamic architecture are all pitched against reactionary and Fascist ideologies. As one of Paulin's voices says: “ 'Go chew acorns / Mr Heidegger / you went with the Nazis"” (Paulin 1993: 109) thus ridiculing the nostalgic groundedness of Heidegger's thought.

All of this runs very much against the grain of the groundedness of much Irish poetry where often what is national is equated with the land and with place and property (we remember Murphy's question "Who owns the land?”). The dinnseanchas tradition is very much a force in Irish poetry and it is clearly in riposte to such a tradition that Paulin describes Heidegger "digging trenches on the Rhine" (Paulin 1993: 106) finding himself knee deep in "red Rhine clay / lignite and gravel" and "in muddy water" (Paulin 1993: 108) in a deliberate, ironic echo of Heaney's famous poem 'Digging'.

In his own representation of the Holocaust, Heaney adapts the dinnseanchas mode so characteristic of his early poetry and uses it to subvert the very localised environment it describes. So the poem 'Anahorish 1944' (from District and Circle, 2006) takes a placename made famous by the Heaney canon and uses it to dwell on the contrast between rural and insular realities versus historical realities. The poem describes the arrival of American soldiers en route for Normandy:

We were killing pigs when the Americans arrived.

A Tuesday morning, sunlit and gutter-blood Outside the slaughterhouse. From the main road

They would have heard the squealing,

Then heard it stop and had a view of us In our gloves and aprons coming down the hill.

(Heaney 2006: 7)
The illusion of Heaney's pre-lapsarian rural childhood is punctured by the squealing pigs whose death anticipates what these soldiers will find once they reach mainland Europe. Another poem 'A Sofa in the Forties' (from The Spirit Level, 1996) combines the themes of history and ignorance by once again invoking the insulation of a 1940s Irish rural upbringing which the adult poet now realises was falsely innocent. The poem describes a children's game and the following two sections of this four part poem were reproduced in the 2008 Holocaust Memorial Day official pamphlet distributed at the Mansion House, Dublin on Sunday 27 January 2008:

All of us on the sofa in a line, kneeling Behind each other, eldest down to youngest, Elbows going like pistons, for this was a train And between the jamb-wall and the bedroom door Our speed and distance was inestimable. First we shunted, then we whistled, then Somebody collected the invisible For tickets and very gravely punched it As carriage after carriage under us Moved faster, chooka-chook, the sofa legs Went giddy and the unreachable ones Far out on the kitchen floor began to wave.

$$
* * *
$$

We entered history and ignorance Under the wireless shelf. Yippee-i-ay Sang 'The Riders of the Range'. HERE IS THE NEWS,

Said the absolute speaker. Between him and us A great gulf was fixed where pronunciation Reigned tyrannically. The aerial wire Swept from a treetop down in a hole Bored in the window frame. When it moved in wind,

The sway of language and its furtherings Swept and swayed in us like nets in water Or the abstract, lonely curve of distant trains As we entered history and ignorance.

(Heaney 1998: 397-398)

In the remote atmosphere of 1940s Ulster, the $\mathrm{BBC}$ news hardly impinges on the children's game as they innocently mimic the "abstract, lonely curve of distant trains" travelling through Europe with their human cargo. The children enter the historical field and 'A Sofa in the Forties' confirms that there is no absolutely innocent, originary starting point. There can only be the enjoyment of childhood ignorance before historical understanding wipes away illusions. It is as if 
these children, to borrow Tom Paulin's words, are seen to be "Plunging from stillness into history" (Paulin 1993: 34).

Another poem (from District and Circle, 2006), perhaps written in the wake of the September 11 attacks on the World Trade Centre, is simply titled 'Anything Can Happen':

Anything can happen, the tallest towers Be overturned, those in high places daunted, Those overlooked regarded. Stropped-beak Fortune Swoops, making the air gasp, tearing the crest off one, Setting it down bleeding on the next.

(Heaney 2006: 13)

The sheer arbitrariness of history is invoked here and we sense in Heaney's poetry the ineluctability of historical processes. We are all implicated regardless of age or nationality and it is hard to remain an innocent bystander for long. Of course, the concentration camps were never foreseen or envisaged, and their horror was all the more shocking because they seemed to stretch all sense of previously imaginable reality, just like the attacks in New York in 2001.

The unimaginable realities of the deathcamps and the postwar disbelief at what had actually happened is of course a dominant theme of any form of art which deals with the Holocaust. These very sentiments are expressed by poet Pearse Hutchinson in a poem 'Ostfriesland' (from Barnsley Main Seam, 1995) set in postwar Holland:

\footnotetext{
I remember Elie Cohen the Dutch rabbi telling the Dutch, after that war:

Don't think it couldn't happen here, it could happen anywhere, even in Holland.
}

(Hutchinson 2002: 232)

In a number of plangent Holocaust poems, Hutchinson takes us on a mini-European tour following a bohemian and cosmopolitan itinerary which reflects the well-travelled poet's deliberate choice of distance from the insular realities of 1940s and 1950s Dublin in which he grew up. So the poem 'Odessa' (again from Barnsley Main Seam, 1995) contrasts Irish and Dutch attitudes towards the Jews:

Called a Jew

six times:

once in middle age

five times in youth

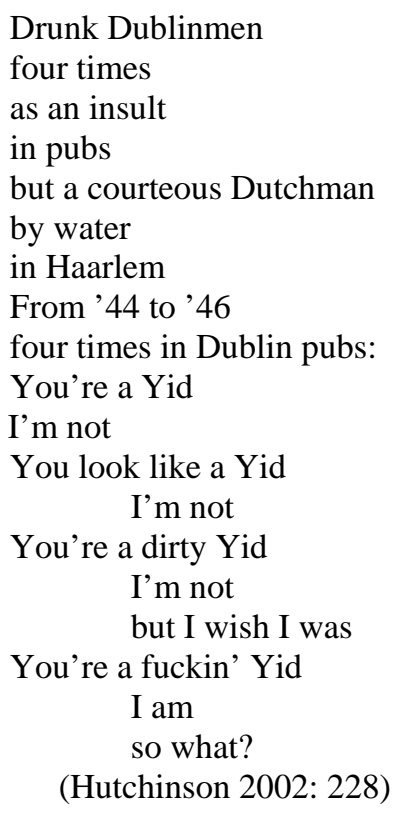

This bar-room anti-Semitism of course echoes James Joyce's more famous confrontation between Leopold Bloom and the Citizen in Ulysses and the attitudes on display are uninteresting, a reflex set of prejudices based on ignorance which the poet resists. In this poem, the ignorance of the Dublin barflies is contrasted with the "courteous Dutchman" whom Hutchinson meets in Haarlem, northern Holland in 1952 and who casually alludes to the Dutch deportations as a needless calamity:
After a pause:
There used to be thousands of them here
before the war
many in kaftans
The Germans took them away
After another pause:
They never did us any harm
not that I could see

(Hutchinson 2002: 229)

This leaves Hutchinson wondering at this stranger's "true Dutch courage and courtesy" (Hutchinson 2002: 229) and such sentiments of gratitude and wonder are expressed several times in Hutchinson's Holocaust poems, as for example his praise for "the rich prose / of a great storyteller Itschak Leib Peretz / in the rich voice / of Zvi Hofer" (Hutchinson 2002: 233) on a Yiddish recording sent to him by Dutch friends. The cosmopolitan joy found in Hutchinson's Holocaust poems sits uneasily but, I would suggest, deliberately against the grim realities of round-ups and deportations from urban centres in Holland during the war. Hutchinson pitches cosmopolitan freedom 
against Nazi terror so that the potential subversiveness of urban living is contrasted with the well-known Nazi predilection for rural tradition in the mode evoked by Heidegger. So, in another poem 'Judengasse', a heavydrinking crowd of urban intellectuals, Hutchinson among them, find their way to a depopulated "Jewish lane" where one of their number "the novelist William Samson" performs "a series of cartwheels along the wet lane to / its empty end" (Hutchinson 2002: 262). This urban high-spiritedness is confirmed in the poem's final lines:

A year or so later, Swiss Cottage,

He gave me a Jewish lunch.

Chicken livers with lemon I'd never eaten before.

They positively melted in the mouth.

(Hutchinson 2002: 263)

It is as if bohemian comradeship is some compensation for the depredations of history. The cosmopolitan is equated with the freedom, reawakened after the war, which was denied by the Nazis. In terms of Irish realities, some of Hutchinson's best-known poems (such as 'Boxing the Fox') deal with pub-crawling, free-wheeling antics which are the direct opposite of Nazi 'arbeit macht frei' ideologies.

In his study of Race in Modern Irish Literature and Culture (2009), the critic John Brannigan identifies national attitudes towards the body, specifically the 'cosmopolitan body', as an important benchmark of national attitudes towards what is potentially deviant or subversive or non-national:

In the Irish Free State, as Michael Mays argues, the "pervasive obsession with national regeneration", a feature common to many countries in the 1920s and 1930s, was particularly acute. The vigorous defence of the family as the basic and analogous unit of the state, the enshrinement of the primary role of women as mothers, the prohibition of all forms of contraception, and the social stigmatisation of childbirth outside marriage were the most obvious ways in which efforts were made to influence biological regeneration. But related to the biological concerns of the state were also ... the biopoetical practices of national identity, which relied upon the development of codes of physical and aesthetic conduct in relation to bodily practice. The process by which the body was to be disciplined and trained as a specifically national body, exemplifying national criteria of morality, taste and beauty, depended upon the cultivation of affects of revulsion from deviant bodily practices (Brannigan 2009: 158).

In the eyes of the Irish State in the years following Independence, even minor individual choices of clothing or wearing of make-up were frowned upon. The 'cosmopolitan body' was seen as deviant in its denial of the Catholic assumptions Brannigan mentions. And we are not that far away here from the extreme eugenic and biological tyranny of the Nazis whose dictatorial attitude towards the body was mirrored in less extreme ways by other European nations in the 1920s and 1930s, including Ireland. Hutchinson's cartwheeling 'cosmopolitan body' rejects all of the assumptions of "biopoetical practices of national identity" which he equates with Fascism and which he resists by way of celebrating urban postwar freedoms.

The freedom to wear what you like and to express oneself according to one's own taste or ethnic identity is the theme of an unusual Holocaust poem by Paul Durcan titled 'The Hat Factory' (from Teresa's Bar, 1976). This is a poem about two extremely unusual business ventures in the west of Ireland during the 1940s, ventures which, in the eyes of the Department of Justice, legitimated some Jewish immigration to Ireland. Two hat factories were transplanted into Ireland by Jewish entrepreneurs from the Continent, one opened in Galway in 1937 and another, 'Western Hats', in Castlebar in 1940. Of course, the sole purpose of these factories, from the point of view of their Jewish owners, was to enable their Jewish families to relocate to Ireland from the Continent even though local employment for Irish people would have been more of a governmental priority. Writing about the hat factory in Castlebar, Durcan meditates:

Myself, I am thinking of the local hat factory,

Of its history and the eerie fact

That in my small town I have never known

Anyone who worked in it

Or had anything to do with it at all;

(Durcan: 1993: 19)

Durcan goes on to consider the diversity of headgear throughout the world ("I speculate / ... as to what kind of hats they make", Durcan 1993: 19) and gives us a loghorreic list which includes: black birettas, top hats, the Pope's skull cap, the black homberg, the Egyptian 
fez, the Bedouin's kefia, bonnets and boaters, the silken turban, bishop's mitres, Napoleonic tricorns, amongst many others, which suggest hats and their wearers as a universal cultural principle of identity and freedom. The hat in this poem assumes the same dignity within absurdity as it does in Beckett's Waiting for Godot. So Durcan continues his meditations by expressing the ideal of unity in diversity which is, we assume, the first principle of tolerance and the best defence against prejudice and xenophobia:

And I think of all the nationalities of Israel

And of how each always clings to his native hat, His priceless and moveable roof,

His hat which is the last and first symbol

Of a man's slender foothold on this earth.

(Durcan 1993: 20)

If we consider a second poem by Durcan, 'The Jewish Bride' we find him using Holocaust imagery in an altogether different mood. This is one of Durcan's painting poems and the Jewish bride of the title comes from a portrait by Rembrandt hanging in the Rijksmuseum, Amsterdam. The painting presents, according to traditional interpretations, a Jewish father tenderly bestowing a necklace on his daughter on her wedding day. It has been described as "one of the greatest expressions of the tender fusion of spiritual and physical love in the history of painting" (Bull, Dibbets, Manuth and de Wetering 2006: 132).

Durcan's poem is about the breakdown of a marriage set against the backdrop of the fate of Dutch Jews during the war. The poem fuses three women: the Jewish bride of the painting, three women: the Jewish bride of the painting, the poet's wife Vanessa and the teenage Holocaust victim Anne Frank. Within this triangular frame, Durcan casts himself as the jackboot Nazi while his estranged wife is presented as "A Jewish Bride who has survived the death camp" (Durcan 1991: 103). It is a remarkably magnanimous poem which blesses his former wife's freedom and apportions blame for the broken marriage firmly on the poet himself whose "swastika eyes" and "gestapo voice" (Durcan 1993: 103) have put the marriage under self-confessed strain. This poem is also typically (for Durcan) sympathetic to women as victims of masculine violence, including the Holocaust. The poet's wife is reborn in the streetscape of Amsterdam free of her ex-husband's tyranny. Like
Hutchinson, it is an urban freedom that even the ghosts of the past (of the Holocaust or of personal pain) cannot undo:

The miracle is that you survived me.

You stroll about the malls and alleyways of

Amsterdam,

About its islands and bridges, its archways and jetties,

With spring in your heels, although it is winter;

(Durcan 1993: 102)

This is a deeply humane and humble poem written in a movingly confessional mode very different from the surrealist comedy of 'The Hat Factory'.

The strong topographical element in Heaney's poetry as well as in Paul Durcan and Pearse Hutchinson stands in marked contrast to the poetry of Thomas Kinsella whose collections Downstream (1962) and Nightwalker (1968) can be seen as a decisively eloquent move towards a modernist and internationalist aesthetic with minimal topographical reference points. Nonetheless, locality persists to some degree, on an historical plane, so that the matter of Ireland is never far from Kinsella's locus of concerns. Indeed, it is the intertwining of Irish and European history which makes Kinsella's allusions to the Holocaust all the more pertinent. In his prose, Kinsella has referred to his sense of the 'falleness' of civilization after the Holocaust and his "Sea of Disappointment" (Kinsella 2007: 54) is very much grounded in this feeling that civilization has been fatally compromised by the Holocaust. For Kinsella, the First World War began a process of unravelling of European civilization which the Holocaust completed. This is the true arrival of Yeats' "rough beast" in his famous poem 'The Second Coming'. As Kinsella writes in his essay ‘The Divided Mind':

It was no news that the human mind was an abyss, and that the will, just as much as the imagination, was capable of every evil. But it was something new that creatures out of Hieronymous Bosch should have materialised in the world, formally inflicting and enduring suffering beyond all reason, in obedience to a diabolic logic ... The coming to reality of these apparently fantastic images is an inner catastrophe; we have opened up another area of ourselves and found something new that horrifies, but that even more intensely disappoints. The realisation of this disappointment 
seems to me the most significant thing in contemporary poetry: it is the source of that feeling of precariousness which is to be found in the best poets now living. (Kinsella 2009: 37)

The internal/external disappointment registers strongly in some of Kinsella's best known poems. In 'Downstream', a physical boat journey 'Toward Durrow Wood' (Kinsella 2007: 30) is also a journey into some kind of psychological 'heart of darkness' in which Kinsella evokes "the European pit" with its "nude herds of the damned" (Kinsella 2007: 30-31). Equally, the journey in 'Nightwalker' also registers a dark interiority via reference to the "blazing fat" and "oven door" of the Holocaust (Kinsella 2007: 48). Further Holocaust allusions can be found in the fragment 'All is emptiness / and I must spin' from 'From the Land of the Dead' and in 'Drowsing over The Arabian Nights'. For John Goodby, Kinsella's “gothic modernism” (Goodby 2000: 76) is part of his sense of 'other' histories, especially the dual heritage of the Irish and English poetic traditions in Ireland. If gothic as a genre is seen to trace 'the other' or other side of the Enlightenment ethos, then the Holocaust is its apocalyptic climax and the end of any Enlightenment illusions about the virtues of civilization. The "seven hundred years accurst” (Kinsella 2007: 30) of Irish history alluded to in 'Downstream' suggests this idea of an historical other in the Irish nation in respect to Britain, a comparison which acts like the binary paradigms often evoked in post-colonial theory. Nonetheless, as Goodby implies, the direct juxtaposition of the Holocaust with Irish history in 'Downstream' strikes a discordant note even if one allows the premise that the Irish and the Jews share a common history of persecution. The historical specificity of the Holocaust rests uneasily with the diffuse suffering of the Irish people across seven centuries, even though Jews can also trace a history of persecution. Perhaps Kinsella's deployment of Holocaust imagery is best seen in the context of his emergence as an important post-Yeatsian poet who manages to escape (unlike Clarke and Kavanagh) some of the anxiety of Yeats' influence both by using new forms (especially with the Peppercanister series), but also by registering a sense of disappointment in the present which is different in kind from Yeatsian disdain for modernity or Kavanagh's or Clarke's quarrels with Ireland. For Kinsella, the Holocaust is an inescapable part of modern consciousness and he is one of the first Irish poets to register this so that even in poems with no historical references, we feel the psychological weight of modern history upon Kinsella's aesthetic.

There is a strong moral centre to Kinsella's poetry as indeed with most of the poets under discussion here. However, an important response by Paul Muldoon to the Holocaust, 'At the Sign of the Black Horse, September 1999’ from his 2002 collection Moy Sand and Gravel, superficially appears to blur the subject matter with which it deals. Typically for Muldoon, the poem is a miscellany of ideas and images from contemporary America which juxtaposes a range of other reference points including: Auschwitz and the Holocaust, Prohibition America, "groundbreaking Irish navvies" (Muldoon 2002: 79) who built the canal in New Jersey where the poet walks with his infant son Asher, Yeats' 'Prayer for my Daughter' and, in the words of the blurb of Moy Sand and Gravel, "a welter of traffic signs and slogans, along with the spirits of admen, hardware storekeepers, flim-flammers, fixers and other forebears". While Muldoon has sometimes been accused of post-modern tricksiness, a poet where style is at least as important as substance, this poem has an authenticity, with quasi-confessional or autobiographical elements, which lend a genuine pathos and solemnity to the Holocaust subject matter. This pathos gives credence to the important claim by Rajeev S. Patke that: "beneath the fun and games, beneath the modishly postmodern and poststructuralist disavowal of agency sits a poet who is not all that different from the Arnold, Auden and Heaney that Muldoon castigates in his Oxford lectures" (Patke 2008: 288). An important anchor of the moral sensibility in Moy Sand and Gravel is Muldoon's role as a father which he celebrates in 'At the Sign of the Black Horse, September 1999' and also in the shorter poem 'The Grand Conversation' in which Muldoon conjures up a conversation with his wife Jean Hanff Korelitz about their divided heritage (the Yeatsian parallel is striking here also in the dialogic form Muldoon uses):

She. My people came from Korelitz where they grew yellow cucumbers and studied the Talmud.

He. Mine pored over the mud of mangold- and potato-pits or flicked through kale plants from Comber 
She. Mine would lie low in the shtetl when they heard the distant thunder stolen by the Cossacks.

$H e$. It was potato-sacks

lumped together on a settle

mine found themselves lying under, the Peep O’Day Boys from Loughgall making Defenders of us all.

(Muldoon 2002: 41)

By referring to Russian anti-Semitism in a family conversation in the USA, Muldoon reminds us that the 'everydayness' of the Holocaust also has a strong familial dimension. A major legacy of the Holocaust is the mutilated family trees of many Americans whose ancestors fell victim to the Nazis. Equally, Irish diasporic consciousness is not far away from its Russian counterpart and these shared roots and shared rootlessness in fact seem to give solid ground to the marriage. It is in this familial context that Muldoon finds his most assured moral voice.

This brief survey would be incomplete without considering two major Irish poems written in elegiac mode about the Holocaust: Harry Clifton's 'Benjamin Fondane Departs for the East' from his prize-winning 2007 collection Secular Eden and Derek Mahon's 'A Disused Shed in Co. Wexford' from The Snow Party (1975). Clifton's poem is a meditation not just on history, or even Jewish history, it is a complex presentation of the provisionality of all of our lives, a provisionality which was exacerbated in the radical uncertainty of interwar Paris and the Occupation as it was actually experienced by Samuel Beckett and also by the subject of the poem, Jewish refugee-poet Benjamin Fondane. Originally from Romania, Fondane was born in 1898 as Benjamin Fundoianu and moved to Paris in 1922 just as Clifton himself lived in the French capital for much of the 1990s and where Fondane's Collected Poems were finally published in French in 1998. These criss-crossing lives remind us of the fate of so many East European Jews, driven westward to escape persecution. Clifton's poem captures the massive human displacement of the war and the fate of Fondane reminds us of another East European Jew, Paul Celan (born: Paul Antschel in 1920), who settled in Paris in 1948 following wanderings from his homeland in Bukovina in modern Ukraine, to the Romanian capital Bucharest and thence to Vienna and Paris.
Celan's life, no less than Fondane's, is indicative of the enormous ethnic, familial and linguistic dislocations of the war. Clifton provides the biographical background to this poem in an essay published in The Dublin Review in Spring 2005 ('Shylock's lament'), but we can sense from the poem itself the radical contingency and adversity of those years:

Look at us now, from the vanished years Paris between the wars.

Penelopes and Juliets, pimps and racketeers Of sugar and tobacco. Boys and girls

With stars on their lapels, who sleep on straw Like everyone else, and carry out the slops.

And who could deny we're equals, under a Law

Annihilating us all? Conformists, resisters,

You I would never abandon, my own soul-sister,

Drinking brassy water from the taps

Of Drancy, where time and space are the antechamber

To our latest idea of eternity -

Trains going east in convoys, sealed and numbered,

To an unknown destination. Pitchipoi

As the wits describe it, after the Yiddish tale -

A village in a clearing, zlotys changed for francs,

Children at their books, the old and frail

Looked after, and the rest suspiciously blank

On the postcards drifting like dead leaves

Back from that other world we are asked to

believe in.

(Clifton 2007: 199)

The significance of Clifton's poem, at least in an Irish context, is that it presents the legacy of Fondane with a dignity and pathos which owe nothing to Irish experience but rather seem to be a product of Clifton's assimilation and ease in a European cosmopolitan environment. As Justin Quinn remarks:

In the work of his first books, Clifton often tries to relate his experiences in Asia or Africa to Ireland, and his own status as a kind of exile. However, in his later work from the 1990s and 2000s, he has become more willing to let the Irish context slip. Many of his poems are portraits of writers, artists and politicians who have become unmoored from their homes and drift through the world constantly negotiating their identity against the background of a foreign language, foreign mores and foreign cityscapes. (Quinn 2008: 190)

Quinn reads Clifton's international aesthetic as part of a wider trend of post-Nationalist, 
post-identitarian poetry in Ireland which manifests, he suggests, in one of his chapter headings, 'The Disappearance of Ireland'. With the Troubles in Northern Ireland, there was, he argues, a tendency for poets to focus on the matter of Ireland so that outstanding Irish poets like Seamus Heaney, John Montague, Richard Murphy and Michael Longley have found their inspiration mainly at home, not abroad. Clifton, by contrast, is a southern Irish poet with a more international frame of reference.

It is one of the achievements of the poetry of Derek Mahon that local subject matter is distanced and at times internationalised so that his most famous poem 'A Disused Shed in Co. Wexford' is both a meditation on the Troubles and also something much larger. In the words of Hugh Haughton, this "much larger predicament”, beyond the poet's native Ulster, is a strategy which enables the mushrooms of the poem to "dramatise the claims of the politically oppressed" wherever they may be found, a strategy which enables the poem "to imagine and represent a different scale of historical witnessing" than is typical in poetry about the Troubles (Haughton 2007: 117). Indeed, Mahon deploys Holocaust imagery throughout the poem but especially in the final two stanzas:

A half century, without visitors, in the dark Poor preparation for the cracking lock

And creak of hinges. Magi, moonmen,

Powdery prisoners of the old regime,

Web-throated, stalked like triffids, racked by drought

And insomnia, only the ghost of a scream

At the flash-bulb firing squad we wake them with

Shows there is life yet in their feverish forms.

Grown beyond nature now, soft food for worms,

They lift frail heads in gravity and good faith.

They are begging us, you see, in their wordless way, To do something, to speak on their behalf

Or at least not to close the door again.

Lost people of Treblinka and Pompeii!

'Save us, save us,' they seem to say,

'Let the god not abandon us

Who have come so far in darkness and in pain.

We too had our lives to live.

You with your light meter and relaxed itinerary,

Let not our naive labours have been in vain!'

(Mahon: 90)

We do not need to dwell on the penultimate stanza with its striking images of the dead and starving in the concentration camps of Europe as they were discovered upon liberation in their weakened and exhausted state; Mahon clearly emphasises the Holocaust here through images we are all now familiar with from films, books and newsprint.

Of equal interest here is Mahon's decision, in the final stanza, to give the victims their own voice. Mahon seems conscious here that any writer who attempts to bear witness to the Holocaust does so with the acute awareness that the true witnesses are those who did not survive, but went to the gas chambers. This is an idea which also percolates Clifton's 'Benjamin Fondane Departs for the East' where, in Fondane's voice, we read:

In the steamroom dissipatings, the bathouse stink, As the people of the Book

Undressed themselves, I learned at last how to think.

(Clifton 2007: 200)

This is "the real Apocalypse" (Clifton 2007: 200), the final moments of six million people, and it is one which the influential Italian philosopher Giorgio Agamben returns to again and again in his book Remnants of Auschwitz where he outlines the impossibility of witnessing the full extent of the atrocity:

The witness usually testifies in the name of justice and truth and as such his or her speech draws consistency and fullness. Yet here the value of testimony lies essentially in what it lacks; at its centre it contains something that cannot be borne witness to and that discharges the survivors of authority. The 'true' witnesses, the 'complete witnesses,' are those who did not bear witness and could not bear witness. They are those who 'touched bottom': the Muslims, the drowned. The survivors speak in their stead, by proxy, as pseudo-witnesses; they bear witness to a missing testimony. And yet to speak here of a proxy makes no sense; the drowned have nothing to say, nor do they have instructions or memories to be transmitted... Whoever assumes the charge of bearing witness in their name knows that he or she must bear witness in the name of the impossibility of bearing witness. (Agamben 2002: 34)

It seems to me that the orchestration of both 'Benjamin Fondane Departs for the East' and 'A Disused Shed in Co. Wexford' allow for this central aporia at the heart of testimony. Both poems enact the subjective voices of the "complete witness" and this poetic ventriloquism is convincing and legitimate. If, as Agamben argues, "the witness, the ethical subject, is the subject who bears witness to desubjectification” 
(Agamben 2002: 151) or in Primo Levi's words "the demolition of man" (Levi 1987: 32), surely both these poets are enacting some kind of reconstructed subjectivity which bears witness to the witness. Indeed, Benjamin Fondane emerges as a forgotten voice who can be reconstructed biographically through Clifton's poem. As Agamben concludes, if the witness-poet "speaks only on the basis of an impossibility of speaking, then his testimony cannot be denied" (Agamben 2002: 164). Therefore, amongst "the places where a thought might grow" (from Derek Mahon's poem) is the aporetic space of saying the unsayable, witnessing as a proxy-witness so that to bear testimony, as Agamben persuasively argues:

... is to place oneself in one's own language in the position of those who have lost it, to establish oneself in the living language as if it were dead, or in a dead language as if it were living .... It is not surprising that the witness' gesture is also that of the poet, the auctor par excellence ... Poets - witnesses - found language as what remains, as what actually survives the possibility, or impossibility, of speaking. (Agamben 2002: 161)

It is a central achievement of both these poets that they have found a possibility for language to enact the voices of "the drowned" while remaining sensitive to the aporetic 'grey zone' in which their poems function. As we have seen, early Holocaust poets were haunted by a crippling sense of the disablement of language. Second generation poets, like Mahon and Clifton, give language back to "the drowned" while still being troubled by the whole question of survival in the realms of language, literature and memory. Just as the mushrooms wait fifty years after the departure of the "expropriated mycologist" (Mahon: 89) for their liberation, so Benjamin Fondane's voice is found in:

\section{... a Paris street}

Old letterbox, a drop-zone for the infinite

In a leaf-littered hallway, where a publisher long ago

Went out of business, and a young man searches In the sibylline mess and the overflow

For a few lost words ...

(Clifton 2007: 200)

This is the ghostly afterlife of which Clifton's poem speaks and the empty space where Mahon's "thought might grow" and it is to these empty spaces that the poet must bear witness. These are not, we should be clear, triumphant reconstructions of lost voices; both poems are aware of the vacuum they must find voice from. It is the expert negotiation of this aporetic situation which lends the poems considerable force and power.

In contrast to Mahon and Clifton's sensitivity to the dilemma of the witness or proxy-witness, at least one example of modern Irish poetry strikes an inauthentic note in its attempt to respond to the enormity of the Holocaust. Micheal O'Siadhail's collection The Gossamer Wall: Poems in Witness to the Holocaust (2002) is problematic because it employs an overarching historical aesthetic using traditional forms which fails to exhibit any formal anxiety about its subject matter. Susan Gubar senses an "incongruity of using traditional and highly regulated prosody in the context of the Holocaust" (Gubar 2004: 455). It seems that, despite Mahon and Clifton's regular forms, they have found a way of approaching the subject obliquely (in Mahon's case via the mushrooms, in Clifton's case through the voice of a forgotten poet) whereas O'Siadhail attempts a full-frontal, microscopic historical recitation of the Holocaust complete with beginning, middle and end, causes and consequences, lessons and warnings. This approach runs the danger of reproducing banal sentiments about the disaster as well as some well-known facts about the death camps without producing any real aesthetic response. For example, how are we to view the following lines of the poem 'Here' from the middle section of The Gossamer Wall titled 'Figures'?:

After disinfection, broken oversized shoes, Berets, blue stripes and the shaven head,

A large yellow Star of David for the Jews,

For criminals green triangles, politicos red.

Elaborate madhouse of rules and signs of caste

Beatings. Starvation. A Kapo's whim and sway

Unravel reason. Here no futures or no past.

Maybe the sap and cunning for another day.

A ladle of watery soup traded on the sly,

A broom filched, a shoe-patch, rations of bread.

Each for himself. Father steals from son.

Parched but denied an icicle Levi asks why?

There's no why here. Shorn and striped biped,

A tattoed number who'd once been someone.

There is something deeply incongruous about writing a regular sonnet sequence (as O'Siadhail does in 'Figures') with this type of 
subject matter, an incongruity Susan Gubar alludes to. There is nothing here that cannot be learned from historical books about the concentration camps, or from the writings of survivors themselves, and such debatable artistry as the above poem exhibits does not add anything to our perception or understanding of the Holocaust or indeed to the Irish contribution to that understanding. If there are certain aesthetic boundaries which poets should adhere to, then writing wellturned sonnets about Auschwitz is surely something which must be discouraged. O'Siadhail's collection, though wellintentioned, has doubtful poetic merit.

We have suggested that recent Irish poetry with Holocaust themes adopts an international approach, an opening-out from the narrow matter of Ireland. We have also seen how local subject matter in Heaney (the family farm in Co Derry), Mahon (the Wexford Anglo-Irish big house, now abandoned) and Durcan (the hat factory in Durcan's native Co. Mayo) can have a European historical dimension thereby developing the dinnseachas tradition and questioning the realities of rootedness. It may be worth reminding ourselves that in his important poem 'Epic', Patrick Kavanagh frames his choice in terms of the relative importance of either "the Munich bother" or the townland disturbances in "Ballyrush and Gortin” (Crotty 1995: 47). His conclusion "Gods make their own importance" (Crotty 1995: 48) - suggests the validity of the parish in a way Heaney found enabling in his early collections but which is significantly modified in his more recent collections. We see not so much a rejection of the local as a qualification of the local based on history, of the kind which Kavanagh's poem also implies.

An important precursor (and possible influence) in this local versus European dimension of Irish poetry is the historian and and essayist Hubert Butler whose work on the Holocaust began to appear, often in Irish journals, in the late 1940s but whose full impact was not felt until the publication of Escape from the Anthill (1985) and The Children of Drancy (1988). Butler's perspective on the Holocaust was extremely unusual for an Irishman. Born in 1900 and educated in England, Butler travelled extensively in Eastern Europe during the 1920s and 1930s including extended stays in Russia,
Croatia and Austria (where he worked in Vienna in 1938-39 for a Quaker organization to help Jewish families escape Vienna following the Anschluss). After the war in 1947 and 1950, Butler returned to Zagreb, Croatia where he undertook archival research into the wartime atrocities committed by the Fascist Ustashe regime there against the Serbian Orthodox and Jewish populations, aided and abetted by both the Nazis and the Croatian Catholic church and in particular Archbishop Aloysius Stepinac whose support for Croatia's wartime dictator Ante Pavelitch cost thousands and thousands of lives amongst the Jewish and Orthodox populations. Butler's outspokenness after the war, especially on the Catholic hierarchy's collusion in the Croatian genocide, at a time when the Vatican sought to defend Archbishop Stepinac's wartime conduct, cost him dearly in his own native land. Butler was criticized in the media, ostracized by local society in his native Co Kilkenny and was obliged to resign his position of secretaryship in the Kilkenny Archaeological Society after speaking openly (in the presence of the Papal Nuncio) at a meeting of the Foreign Affairs Association in Dublin about Stepinac's role in the genocide which Butler had uncovered by examining wartime newspaper cuttings and other documents in the Municipal Library, Zagreb in 1947.

Butler is a paradoxical figure. In an age of professional scholarship, he has defended the role of the amateur historian, especially the local historian. Despite the international subject matter of many of his essays, he has claimed that all his work is rooted in Ireland so that "even when [his] essays appear to be about Russia or Greece or Spain or Yugoslavia, they are really about Ireland" (Butler 1996: 4). In order to escape from the anthill of second-hand experience, Butler suggests that we must value local concerns and our local environment as a premise for engagement with the wider world. Considering Butler's widely-travelled oeuvre, it is surprising to find him echoing, in an Anglo-Irish way, the same sentiments as Kavanagh's poem. However, Butler is also an astute and clear-eyed historian and a very wellinformed commentator on European events 1939-1945 in regions not often surveyed by Irish scholars. Butler may be an important presence behind some of the writers considered 
here albeit someone whose influence in hard to trace because of the sporadic publication of his work up to 1985.

Chris Agee praises Butler's "ethical imagination" (Agee 2003: 146) in an essay on 'The Stepinac File' assembled by Butler. What Agee identifies in Butler is his acute historical sense of the psychology of someone (Archbishop Stepinac) who does great evil by tacit collusion with authorities while maintaining the aura of sanctity befitting to his position:

Butler does not simply lay charges at the door of the Archbishop. With the forensic eye for inner detail that characterizes all his writing on personality, he is interested in something more important, more exemplary of a social process, than simple moral condemnation. Butler avoids any sense of anathematizing the character of Stepinac, whose courage, piety and personal kindliness he emphasizes. Moreover, there is no suggestion that the Monsignor belongs to the same moral universe as actual war criminals like Pavelitch, Artukovitch and Eichmann. Nonetheless, Butler does not shirk from making a decisive comparison with them in the matter of the process of behaviour. For Butler, Stepinac is another avatar of the Organization Man, subset Ecclesiastical. In a period of Alice-inWonderland values, institutional order itself, in a sense, is the problem. 'The Organization Man's fatal respect for orderliness' becomes integral to the vastness of the criminal enterprise. In bureaucratic cases like Eichmann and Artukovitch, who were dutiful cogs in the momentum of the state, the role of the Organization Man is now well-understood. But what I think Butler saw in the figure of Stepinac - what he saw firsthand in the Municipal Library in Zagreb - is a less obvious form of the phenomenon, a corollary of the first, though perhaps no less essential to that breakdown in the ethical machinery: the Organization Man in proximity to crime. (Agee 2003: 152)

Hannah Arendt's formulation of the 'banality of evil' becomes, in Butler's essays about Stepinac, the "gentility of evil" (Agee 2003: 152) but is no less lethal and culpable for that. In this, Butler's analysis agrees with much of what has been written about the mechanics of Nazi deportation and extermination. In the moral vacuum of wartime Europe, astonishing crimes occurred in the most routine way. Thus Butler argues, regarding the deportation of 4051 Jewish children from Gare d'Austerlitz, Paris to Auschwitz in July-August 1942:
... to kill and burn 4051 children after transporting them to Poland was a huge cooperative endeavour, in which thousands of French and German policemen, typists, railway officials, gas-fitters and electricians were engaged. It was composite villainy, and when you try to break it down, there are no villains, just functionaries ... (Butler 1988: 187)

The strength of Butler's essays is his eye for the perspicacious detail and the deportation of these children is amongst the most pitiful spectacles of the war. But key to his arguments is the idea of the local and specific versus the international and diffuse. For Butler, the Holocaust is made possible by the mechanics of industrial society in the hands of criminal ideologues in which the chain of responsibility makes everyone and no-one culpable.. For Butler, a smaller and more organic society provides some mainstay against these threats and "it is not a coincidence" he argues "that two small countries, Denmark and Bulgaria, stemmed the flow to Auschwitz better than any of their more powerful neighbours on the continent” (Butler 1988: 194). Local knowledge and identity can, in certain circumstances, act against the facelessness of evil, according to Butler.

In the more globalized environment we currently inhabit, it is hard to see how Butler's valorization of the local can help us if a similar political darkness to the Nazis were to befall Europe in the twenty-first century. Indeed, one might suggest that the instantaneity of communication networks and the ease with which information can flow, could work as a bulwark against future oppression since it is very hard, nowadays, for tyranny and murder to exist without general knowledge circulating. Indeed, the fate of the children of Drancy was unknown to the inhabitants of Paris in 1942; only from 1943 did news of the Nazi extermination policy circulate as unconfirmed rumour in Europe, although clearly most people who wished to consider the matter were aware of the extreme cruelty of what was being undertaken in Paris. Rather than rely on local networks and local knowledge, it may be more pertinent to consider some of the advantages of our interconnected world where travel, cultural and ethnic diversity and intercultural communication are far more extensive than for those of Butler's generation. This approach is suggested by the poet George Szirtes whose own family emigrated from Hungary to Britain 
in the 1950s and whose poetry is deeply concerned with the historical legacy of the Holocaust. In an essay about his return to Budapest in the 1980s to reclaim his dual identity as an Anglo-Hungarian writer, Szirtes eloquently advocates a post-Nationalist, postethnic world and speaks of his own sense of belonging and not-belonging in his adopted country, England:

It is sometimes painful to be 'en Angleterre, mais pas anglais'. Sometimes I feel as free as a bird. Sometimes I think I am a herald of the world to come, and that we are beginning to see the end of national states, watching instead waves of people and fragmentary cultures swirling around in an economically determined amplitude that stretches over specific areas of the earth. Being without a home does not have to mean being without history or without human passions. I am all too full of both, I fear. (Szirtes 2001: 121)
It may well be that by sharing cultural, as well as political and economic sovereignty, European nations can avoid or minimise the dangers of future ethnic conflict and genocide. Recent conflicts in the Balkans show that nationalism remains a real and present danger even in our post-Holocaust world. For Irish poets, the benefits of both local and international perspectives are obvious and we have seen how twentieth-century Irish poets are aware of these crossovers and connections between the local and international. Szirtes vision of a post-national Europe in which cultures and identities flow into one another could be liberatory for the individual writer, not least for Irish writers, as long as we do not lose sight of the darker lessons of history

\section{Works Cited}

Agamben, Giorgio. 2002. Remnants of Auschwitz: The Witness and the Archive, trans. Daniel Heller-Roazen. New York: Zone Books.

Agee, Chris. 2003. “The Stepinac File”. Unfinished Ireland: Essays on Hubert Butler, ed. Chris Agee. Belfast: Irish Pages/The Butler Society.

Beckett, Samuel. 1986. Collected Poems 1930-1978. London: John Calder. . 1995. “The Capital of Ruins”. The Complete Short Prose 1929-1989, ed. S.E. Gontarski. New York: Grove Press. 275-278.

Brannigan, John. 2009. Race in Modern Irish Literature and Culture. Edinburgh: Edinburgh University Press.

Bull, Duncan, Taco Dibbets, Volker Manuth and Ernst van de Wetering, eds. 2006. Rembrandt-Carravaggio. Amsterdam: Rijksmuseum.

Butler, Hubert. 1988. The Children of Drancy. Dublin: The Lilliput Press. 1996. Independent Spirit: Essays. New York: Farrar, Straus and Giroux.

Clifton, Harry. 2005. "Shylock's lament”. The Dublin Review, 18 . 29-39. . 2007. Secular Eden: Paris Notebooks 1994-2004. Winston-Salem: Wake Forest UP.

Crotty, Patrick, ed. 1995. Modern Irish Poetry: An Anthology. Belfast: Blackstaff Press.

Durcan, Paul. 1993. A Snail in My Prime: New and Selected Poems. London: Harvill.

Foster, R.F. 2001. The Irish Story: Telling Tales and Making it Up in Ireland. London: Penguin.

Goodby, John. 2000. Irish Poetry Since 1950: From Stillness into History. Manchester: Manchester UP.

Gubar, Susan. 2004. “The Long and the Short of Holocaust Verse”. New Literary History 35.3.

Haughton, Hugh. 2007. The Poetry of Derek Mahon. Oxford: Oxford UP.

Heaney, Seamus. 1998. Opened Ground: Poems 1966-1996. London: Faber and Faber. 2006. District and Circle. London: Faber and Faber.

Hutchinson, Pearse. 2002. Collected Poems. Oldcastle: Gallery Press.

Keogh, Dermot. 1998. Jews in Twentieth-Century Ireland: Refugees, Anti-Semitism and the Holocaust. Cork: Cork UP.

Kinsella, Thomas. 2007. Selected Poems. Manchester: Carcanet.

Kinsella, Thomas. 2009. Prose Occasions 1951-2006, ed. Andrew Fitzsimons. Manchester: Carcanet.

Levi, Primo. 1987 (1969). If This is a Man, trans. Stuart Woolf. London: Abacus.

Mahon, Derek. 1999. Collected Poems. Oldcastle: Gallery Press. 
Muldoon, Paul. 2002. Moy Sand and Gravel. London: Faber and Faber.

Murphy, Richard. 2000. Collected Poems. Oldcastle: Gallery Press.

Nixon, Mark. 2007. “ ‘Text-Void’: Silent Words in Samuel Beckett and Paul Celan”. Beckett’s Literary

Legacies, ed. Matthew Feldman and Mark Nixon. Newcastle: Cambridge Scolars Press. 152-168.

Nora, Pierre. 1989. “Between Memory and History: Les Lieux de Mémoire”, trans. Marc Roudebush. Representations 26. 7-24.

O’Siadhail, Micheal. 2002. The Gossamer Wall: Poems in Witness to the Holocaust. Newcastle: Bloodaxe Book.

Patke, Rajeev S. 2008. “' 'Responsibility’ and 'Difficulty’ in the Poetry of Paul Muldoon”. Criticism 50.2. 279300.

Paulin,Tom. 1993. Selected Poems 1972-1990. London: Faber and Faber. . 2002. The Invasion Handbook. London: Faber and Faber.

Quinn, Justin. 2008. The Cambridge Introduction to Modern Irish Poetry 1800-2000. Cambridge: Cambridge UP.

Schlink, Bernhard. 2007. The Reader, trans. Carol Brown Janeway. London: Phoenix.

Szirtes, George. 2001-02. “Fables of home”. The Dublin Review 4. 107-122.

Received 10th October 2010 Revised version 13 February 2011

Benjamin Keatinge is Head of English at the South East European University, Tetovo, Macedonia where he teaches English literature. He holds a doctorate on Samuel Beckett from Trinity College Dublin and he has published articles on Beckett in the Irish University Review, the Journal of Modern Literature as well as in a recent collection of essays on Endgame/Fin de Partie published by Presses Universitaires de Rennes, 2009. He recently published (as co-editor) a volume of critical essays on Irish poet Brian Coffey titled Other Edens: The Life and Work of Brian Coffey (Irish Academic Press, 2010). He has also contributed essays on poets Richard Murphy and Pearse Hutchinson to edited volumes as well as reviews to Poetry Ireland Review, the Irish University Review, the European English Messenger and The Beckett Circle. 